Ethiopian Journal of Environmental Studies \& Management 7(3): 218 - 234, 2014.

ISSN:1998-0507

doi: http://dx.doi.org/10.4314/ejesm.v7i3.1

Submitted: October 30, 2013

Accepted: March 24, 2014

\title{
CHALLENGES OF CAPTIVE BREEDING AND RE-INTRODUCTION OF SELECTED PRIMATE SPECIES INTO THEIR NATURAL HABITAT IN CROSS RIVER STATE, NIGERIA
}

\author{
IJEOMAH, H.M. AND CHOKO, O. P. \\ Department of Forestry and Wildlife Management, University of Port Harcourt, P.M.B.5323, Port \\ Harcourt, Rivers State, Nigeria
}

\begin{abstract}
This study investigates the factors influencing successful captive breeding and re-introduction of selected primate species in the wild using Centre for Education, Research and Conservation of Primates and Nature (CERCOPAN) and Drill Rehabilitation and Breeding Center (PANDRILLUS) of Cross Rivers State as case studies. Data for the study were collected through interviews, observations and a set of structured questionnaire. Data collected were presented in form of frequency and percentages, while Chi square was used to test for associations. The most pressing challenges in CERCOPAN include; inability of released primates to cope in the wild (34.78\%) as they returned back to the breeding centres (30.34\%); lack of monitoring equipments (26.09\%) and the long period of monitoring released primates (26.09\%); raising of self-sustaining population (21.74\%) and unavailability of release sites for some species (17.39\%). Re - introduction has not been carried out in PANDRILLUS since the inception of the project because of inadequacy of protective measures (54.17\%), lack of monitoring equipments (41.67\%), insufficient number of experts (33.33\%), health challenges (29.17\%) and insecurity (83.33\%). CERCOPAN overcomes these challenges through constant monitoring (69.57\%), provision of monitoring equipments (26.09\%), soft release (8.70\%) and health screening (8.70\%), while PANDRILLUS, overcomes them through environmental education (87.50\%), purchase of monitoring equipments (79.17\%), provision of radio caller systems (66.67\%) and sourcing of fund from local and foreign bodies (50.00\%). Chi square tests showed no significant associations between awareness level of captive breeding and re-introduction process among project host communities and type of conservation organization $\left(X^{2}=0.54\right)$ at $p \geq 0.05$.; and respondents' level of awareness of the processes involved in captive breeding and re-introduction $\left(X^{2}=0.6484\right)$ and type of conservation organization $(p>0.05)$. Thus the awareness level of the captive breeding centres among host communities is high, but awareness level of the processes involved in captive breeding and re-introduction, among respondents is low in the two institutions.
\end{abstract}

Key Words: Ecological restoration, Wildlife orphanage, Rehabilitation, Conservation organization, Congo Basin, Biodiversity

\section{Introduction}

The high rate of exploitation and gross misuse of natural resources have led to large scale reduction in the number of wildlife species (National Wildlife Federation, 2014). Captive breeding and re-introduction programmes were embarked upon by conservation experts as a strategy to safe endangered species by increasing their population in their natural habitats. In spite of many years of introduction of this programme 'captive breeding and re - introduction of endangered wildlife species' in Nigeria, record has not showed any significant improvement in the conservation status of many of these endangered primate species in Nigeria (Ijeomah et al., 2012). Without proper information and planning on any project that is being embarked on, the project has a higher chance of failing. There is, therefore, a great need to study the challenges related to the various stages of breeding primate species in captivity, and reintroduction of the species into the wild. Various projects on in-situ and ex-situ management of both endangered and non endangered wildlife species have been studied in Nigeria but none of the works has specifically focused on captive breeding and re-introduction of threatened and endemic primate species, whereas the wild population of these primates are continuously decreasing. The few studies on re-introduction of

*Corresponding Author: Ijeomah, H.M.

Email: henryijeomah@yahoo.com 


\section{Challenges of Captive Breeding and Reintroduction of Selected................IJEOMAH \& CHOKO}

populations into the wild were conducted outside Nigeria and the observations made were on different species.

Jim (2010) reported a failed attempt to reintroduce a raptor bird (Bearded vulture) in Tanzania. Also, Kumar (2006) revealed that a breeding programme which began in late 1980's at the Chhatbi Zoo, north India was discontinued in 2002 after many of their nearly 80 lions bred were struck by a mysterious disease aggravated by inbreeding and a weakened gene pool as the breeders tried to cross breed Asiatic and African lions.

Due to several failures experienced in captive breeding and re-introduction programmes over the years in different countries coupled with its attendant time requirement, it is therefore imperative to have a detailed study on the challenges most likely encountered in rehabilitation centres. Through this study, information will be gathered which will be quite relevant in enhancing conservation of primate species and increasing the population of the species in the wild. Captive breeding programme is one of the ex-situ conservation practices advocated by the International Union for the Conservation of Nature (IUCN), and could be a significant technique to avoid total extinction of some threatened species (Kehinde and Ijeomah, 2012). The effectiveness of captive breeding programme in rescuing endangered species from potential extinction depends on the ability of the programme to maintain a self sustaining population of the species in the wild through re-introduction. According to Laidlaw (2001) re-introduction is the release of captive bred or wild caught animals into areas they do no longer inhabit or where their numbers have been seriously depleted within historical range. Reintroduction, therefore, is a commonly used and potentially powerful tool for ecological restoration and endangered species recovery (Macdonald et al., 2002; van Wieren, 2006).

Many endangered species have been saved from extinction through captive breeding and reintroduction programmes. The Point Defiance Zoo and Aquarium bred the Red Wolf (Canis rufus); which was Critically Endangered, in captivity and successfully reintroduced it into the wild on Bulls Island part of the Cape Romain National Wildlife Refuge off the coast of South
Carolina, and later in Alligator River and Pocosin Lakes which are two national wildlife refuges in North Carolina, the United States of America (Defenders of Wildlife, 2012; Fascione, 2006). In 1990 captive bred Red Wolf was also released at three separate sites by the United States Fish and Wildlife Service to create a population of 220 in the wild. The Arabian Oryx, Oryx leucoryx was saved from extinction through captive bred animals that were successfully released into the wild at different times since 1982 (Conservation and Science, 2012).Through successful reintroduction and translocation programme the population of the Golden Lion Tamarin (GLT) (Leontopithecus rosalia) in the wild has increased, its IUCN conservation status was changed from critically endangered to endangered (IUCN, 2013), and protection of its natural Atlantic forest habitat, in Rio de Janeiro (which is one of the world's most endangered biodiversity hotspot) was increased by $140 \%$ (Tamarin Tales, 2010). Collection and ex-situ hatching of egg masses of the critically endangered Ramsey Canyon Leopard Frog (Lithobates subaquavocalis) and returning them to the wild after they have developed beyond the most vulnerable life stage provides survival advantage to the species by protecting their eggs and smaller tadpoles from predators, and allows wildlife officials to release reared frogs into locations that need population augumentation most. Conservation and Science (2012) reported that over 14,000 frogs and tadpoles have been raised and released into the wild. The breeding of many endangered species such as Lion (Panthera leo), Leopard(Panthera pardus) and Pigmy Hippopotamus (Choeropsis liberiensis) in Jos Wildlife Park (Ijeomah et al., 2006) without reintroduction of the species in the wild has not in any way improved the conservation status of these species in the wild.

\section{Objectives of the Study}

The objectives of the study are to:

$>$ assess the general knowledge of workers about captive breeding and re-introduction of primates.

$>$ assess the challenges faced in the captive breeding and re-introduction of selected primate species in the study area. 
$>$ investigate the general problems affecting efficient and effective operations of captive breeding by non-governmental organization.

\section{Methodology \\ Study Area}

The project sites are the Centre for Education, Research and Conservation of Primates and Nature (CERCOPAN) and Drill Rehabilitation and Breeding Centre (DRBC or PANDRILLUS), both in Cross River State, Nigeria (Figure 1). Cross River State is located between latitudes $5^{\circ} 45^{1}$ north and $8^{\circ} 30^{1}$ east and longitudes $5^{\circ} 75^{1}$ north and $8^{\circ} 5^{1}$ east of the equator at the western edge of the GuineanCongolian basin $\left(2.8\right.$ million $\left.\mathrm{km}^{2}\right)$. The State, covering $21,560 \mathrm{~km}^{2}$ is bordered by Cameroon to
$>$ investigate the operational strategies adopted by PANDRILLUS and CERCOPAN in overcoming the challenges mentioned above.

the east, the Nigerian states of Benue, Ebonyi and Akwa Ibom to the north and west, and by the Gulf of Guinea to the south (Forest Resource Solutions, 2006). Rainfall varies from 1800 to $4500 \mathrm{~mm}$ annually with the driest period (longer in the north than in the south) occurring from November to April. There is general decrease in rainfall away from the coastal areas northwards and westwards. The State has an estimated population of about 2 million people (1991 census data) in over 620 recognizable human settlements.

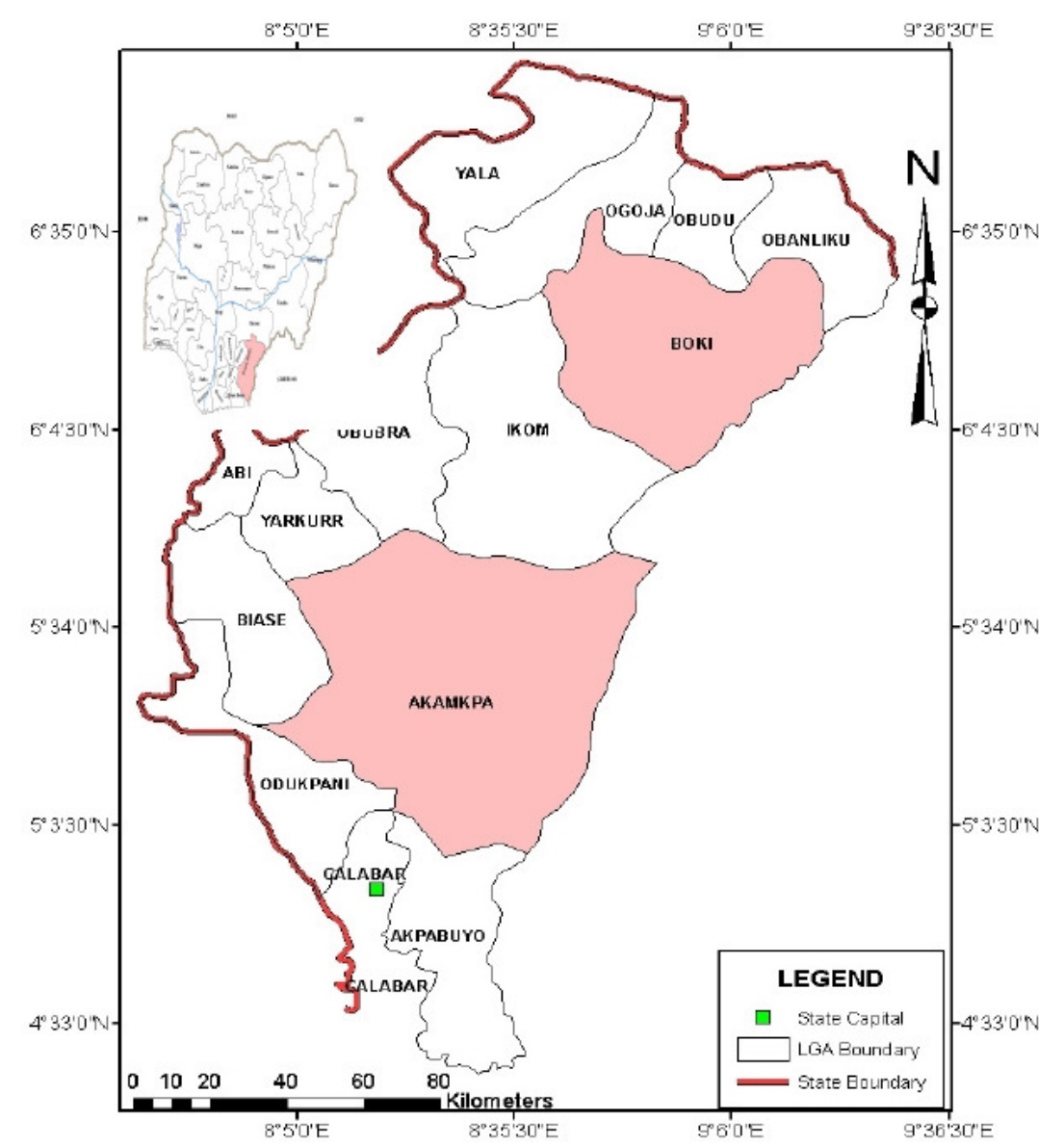

Figure 1: Map of Cross River State showing the study area

Drill Rehabilitation and Breeding Center (PANDRILLUS) or (DRBC) was founded in 1991 and it is the first established primate rehabilitation project in the area. Illegally held drills orphaned by hunting were donated by local citizens or handed over after seizure by 
authorities for rehabilitation and latter reintroduction to the wild. The project has two sites. The original site of PANDRILLUS in Calabar, the State capital serves as the project headquarters, while Drill Ranch in Afi Mountain of Boki Local Government Area, a four hour drive north from Calabar serves as the project's field site (Figure 1). Both sites are open to the public on daily basis at no cost.

The second project site, the Centre for Education Research and Conservation of Primates and Nature (CERCOPAN) was founded in 1995. It is a non-profit making organization dedicated to conserving Nigeria's primate communities through forest conservation, community education and support, primate rehabilitation and research. The project is located in Calabar and occupies an area of $150 \mathrm{~km}^{2}$ (Tusk trust, 2011).

The primate species in CERCOPAN are guenons, red-capped mangabeys, drill monkeys, Preuss's red colobus, Cross River Gorilla and western Chimpanzee. The host community of CERCOPAN is Iko Esai. The projects together protect more than $50 \%$ of the community forest against exploitation from logging and farming. Since the inception of the project, over 160 primates of 6 species have been kept in various stages of rehabilitation.

\section{Data Collection}

Data for the study were collected through the use of structured questionnaire, personal Table 1a: Respondents' awareness of the breeding and re-introduction status of primates in CERCOPAN

\begin{tabular}{|c|c|c|c|c|}
\hline Parameter & Variable & & Frequency & Percentage \\
\hline \multirow[t]{2}{*}{ Primate of interest } & Cercopithecus & mona & 23 & 100.00 \\
\hline & Cercocebus torquatus) & & 23 & 100.00 \\
\hline \multirow[t]{5}{*}{ Way of animal acquisition } & Purchase & & 0 & 0.00 \\
\hline & Seizure & & 6 & 26.09 \\
\hline & Donation & & 23 & 100.00 \\
\hline & Capture from the wild & & 0 & 0.00 \\
\hline & Captive born & & 0 & 0.00 \\
\hline If primates have been & Yes & & 23 & 100.00 \\
\hline \multirow{2}{*}{ breeding? } & No & & 0 & 0.00 \\
\hline & Total & & 23 & 100.00 \\
\hline \multirow{4}{*}{$\begin{array}{l}\text { If re-introduction has ever } \\
\text { been carried out? }\end{array}$} & Yes & & 19 & 82.61 \\
\hline & No & & 2 & 8.70 \\
\hline & No response & & 2 & 8.70 \\
\hline & Total & & 23 & 100.00 \\
\hline $\begin{array}{l}\text { Number of times re- } \\
\text { introduction took place? }\end{array}$ & Once & & 19 & 100.00 \\
\hline If no, why? & Not yet time for release & & 2 & 8.70 \\
\hline
\end{tabular}

observation and indepth interviews. A set of structured questionnaire was administered at random to $68 \%$ of staff of the two organizations. In all, 23 and 24 were administered to staff of CERCOPAN and PANDRILLUS respectively. Data collected with questionnaires were on demographic and social characteristics of staff, staff number, and challenges faced as regards the breeding program, their success and failure since the inception of the program, the knowledge of the workers as regards to the breeding process in overcoming the challenges. The facilities in the project site were observed and assessed; types of primate species in the two sites were also observed. Interviews were conducted with selected knowledgeable staff members of the two establishments who have worked for a minimum of five years.

\section{Data Analysis}

Data collected were presented in form of frequency and percentages while Chi square was used to test for associations.

\section{Results}

\section{Awareness of Breeding and Re-introduction Status of Primates}

Most respondents are aware of the breeding and re - introduction status of primates in the study sites (Tables 1 and 2). and the strategies employed by the establishment 
Table 1b: Respondents' awareness of the breeding and re-introduction status of primates in PANDRILLUS

\begin{tabular}{llll}
\hline Parameter & Variable & Frequency & Percentage \\
\hline Primates of interest & Drills & 24 & 100.00 \\
& Chimps & 24 & 100.00 \\
Mode of animal acquisition & Purchase & 0 & 0.00 \\
& Seizure & 15 & 62.50 \\
& Donation & 19 & 79.17 \\
& Capture from the wild & 0 & 0.00 \\
Having the breeding been & Yes & 24 & 100.00 \\
successful? & No & 0 & 0.00 \\
& Total & 24 & 100.00 \\
\hline
\end{tabular}

Table 2: Chi-square test on Awareness of captive breeding and re-introduction processes among project host communities and type of conservation organization

\begin{tabular}{lcl}
\hline & Level of awareness & \\
Conservation NGO & Low & High \\
CERCOPAN & 4 & 19 \\
PANDRILLUS & 6 & 18 \\
\hline
\end{tabular}

Table 2 shows that there is no significant association between awareness level of captive breeding and reintroduction process among project host communities and type of conservative organization $\left(X^{2}=0.54\right)$ $\mathrm{p} \geq 0.05$.

Table 3: Chi-square test on Awareness of the processes involved in 'captive breeding and reintroduction' among respondents and type of conservation organization

\begin{tabular}{lll}
\hline & Level of awareness & \\
Conservation NGO & Low & High \\
CERCOPAN & 20 & 3 \\
PANDRILLUS & 19 & 5 \\
\hline
\end{tabular}

Table 3 shows that there is no significant association between respondents' level of awareness of the processes involved in captive breeding and re-introduction $\left(X^{2}=0.6484\right)$ and type of conservation organization ( $\mathrm{p} \geq 0.05)$.

Respondents from both CERCOPAN and PANDRILLUS are unaware of the proper seasons for reintroduction of primates ( $4 a$ and $4 b)$.

Table 4a: Respondents awareness of season for animal re-introduction in CERCOPAN

\begin{tabular}{|c|c|c|c|}
\hline Parameter & Variable & Frequency & Percentage \\
\hline \multirow{5}{*}{$\begin{array}{l}\text { Time for re-introduction in the } \\
\text { establishment }\end{array}$} & Rainy season & 1 & 4.35 \\
\hline & Dry season & 3 & 13.04 \\
\hline & All year round & 9 & 39.13 \\
\hline & No response & 10 & 43.48 \\
\hline & Total & 23 & 100.00 \\
\hline \multirow{3}{*}{$\begin{array}{l}\text { If rainy season, why? } \\
\text { If dry season, why? }\end{array}$} & Due to food abundance & 1 & 4.35 \\
\hline & $\begin{array}{l}\text { In order to be feeding them before } \\
\text { the trees start fruiting } \\
\text { In order to ease accessibility }\end{array}$ & 1 & 4.35 \\
\hline & during monitoring & 1 & 4.35 \\
\hline
\end{tabular}


Challenges of Captive Breeding and Reintroduction of Selected.................IJEOMAH \& CHOKO

Table 4b: Respondents awareness of season for animal re-introduction in PANDRILLUS

\begin{tabular}{llll}
\hline Parameter & Variable & Frequency & Percentage \\
\hline Time for re-introduction in & Rainy season & 6 & 25.00 \\
the establishment & Dry season & 0 & 0.00 \\
& All year round & 0 & 0.00 \\
& Not aware & 18 & 75.00 \\
& Total & 24 & 100.00 \\
If rainy season, what are the & Due to plenty food & 6 & 100.00 \\
reasons? & & & \\
\hline
\end{tabular}

Challenges Faced by the Establishments during Re-introduction of Primates

Table 5 shows that the most pressing challenge indicated by the respondents from CERCOPAN is the inability of released primates to cope with the forest situation as they always tend to return to the breeding centres. The others are: inability of the captive bred ones to interact with the wild ones, lack of monitoring equipments and the long period of monitoring the released primates. Re introduction has not been carried out in PANDRILLUS since the inception of the project and hindrances to that are presented in Table 6 . Among them are inadequacy of protective measures $(54.17 \%)$ and lack of monitoring equipments $(41.67 \%)$ while monitoring $(87.50 \%)$ and insecurity $(83.33 \%)$ are major potential challenges.

Table 5: Challenges faced by CERCOPAN during re-introduction of primates

\begin{tabular}{lll}
\hline Challenges & Frequency & Percentage \\
\hline Inability to limit their movement within the protected area & 1 & 4.35 \\
Stressful phenology studies & 1 & 4.35 \\
Encroachment by villagers & 1 & 4.35 \\
Reproduction challenges & 1 & 4.35 \\
Predators & 2 & 8.70 \\
Over familiarities with humans & 2 & 8.70 \\
Selection of the best group for re-introduction & 2 & 8.70 \\
Long period of food provision & 2 & 8.70 \\
Disease infection & 3 & 13.04 \\
Climate challenges & 3 & 13.04 \\
The exercise is stressful & 3 & 13.04 \\
Too many individual of one sex & 3 & 13.04 \\
No release site for some individuals & 3 & 13.04 \\
Raising a self sustaining population & 4 & 17.39 \\
Long monitoring & 5 & 21.74 \\
Lack of monitoring equipment & 6 & 26.09 \\
Inability to interact with wild ones & 6 & 26.09 \\
Returning of some individuals & 7 & 30.43 \\
Inability to cope with the forest situation & 8 & 34.78 \\
\hline
\end{tabular}


Table 6: Hindrances to primate re-introduction in PANDRILLUS

\begin{tabular}{|c|c|c|c|}
\hline Parameter & Variable & Frequency & Percentage \\
\hline If & Yes & 0 & 0.00 \\
\hline re-introduction & No & 24 & 100.00 \\
\hline ever been carried out? & Total & 24 & 100.00 \\
\hline \multirow[t]{14}{*}{ Hindrances to it } & No proper survey of release site & 1 & 4.17 \\
\hline & Few soft release materials & 2 & 8.33 \\
\hline & Season variability & 2 & 8.33 \\
\hline & No previous literatures on release of drill & 2 & 8.33 \\
\hline & No monitoring team & 3 & 12.50 \\
\hline & Is a trial by error stuff & 3 & 12.50 \\
\hline & Stressful and tasking & 3 & 12.50 \\
\hline & Too many of one sex & 4 & 16.67 \\
\hline & They want to ensure that it goes successfully & 4 & 16.67 \\
\hline & Health challenges & 7 & 29.17 \\
\hline & Lack of experts & 8 & 33.33 \\
\hline & Expensive monitoring & 10 & 41.67 \\
\hline & No monitoring materials for release & 10 & 41.67 \\
\hline & Inadequate protective measures & 13 & 54.17 \\
\hline \multirow{5}{*}{$\begin{array}{l}\text { Potential challenges } \\
\text { faced in r re- } \\
\text { introduction }\end{array}$} & Complexity of the exercise & 5 & 20.83 \\
\hline & Attitude of the community towards the project & 6 & 25.00 \\
\hline & Expensive monitoring equipments & 10 & 41.67 \\
\hline & Forest protection/security & 20 & 83.33 \\
\hline & Monitoring & 21 & 87.50 \\
\hline
\end{tabular}

Table 7a: Assessment of primate adaptability after re-introduction

\begin{tabular}{|c|c|c|c|}
\hline Parameter & Variable & Frequency & Percentage \\
\hline How well do newly & Very good & 4 & 17.39 \\
\hline \multirow{5}{*}{$\begin{array}{l}\text { reintroduced ones adapt to their } \\
\text { new environment? }\end{array}$} & Good & 8 & 34.78 \\
\hline & Fair & 3 & 13.04 \\
\hline & Poor & 1 & 4.35 \\
\hline & No response & 7 & 30.44 \\
\hline & Total & 23 & 100.00 \\
\hline \multirow{6}{*}{$\begin{array}{l}\text { How is the survival of the } \\
\text { primate during captive } \\
\text { breeding? }\end{array}$} & Very good & 8 & 34.78 \\
\hline & Good & 10 & 43.48 \\
\hline & Fair & 3 & 13.04 \\
\hline & Poor & 0 & 0.00 \\
\hline & No response & 2 & 8.70 \\
\hline & Total & 23 & 100.00 \\
\hline \multirow{6}{*}{$\begin{array}{l}\text { How is the survival rate after } \\
\text { re-introduction? }\end{array}$} & Very good & 0 & 0.00 \\
\hline & Good & 12 & 52.17 \\
\hline & Fair & 4 & 17.39 \\
\hline & Poor & 0 & 0.00 \\
\hline & No response & 7 & 30.44 \\
\hline & Total & 23 & 100.00 \\
\hline \multirow{6}{*}{$\begin{array}{l}\text { How well do they procure food } \\
\text { for themselves in the wild? }\end{array}$} & Very good & 4 & 17.39 \\
\hline & Good & 5 & 21.74 \\
\hline & Fair & 4 & 17.39 \\
\hline & Poor & 0 & 0.00 \\
\hline & No response & 10 & 43.48 \\
\hline & Total & 23 & 100.00 \\
\hline \multirow{6}{*}{$\begin{array}{l}\text { How is their level of interaction } \\
\text { with other wild individual? }\end{array}$} & Very good & 1 & 4.35 \\
\hline & Good & 1 & 4.35 \\
\hline & Fair & 6 & 26.09 \\
\hline & Poor & 5 & 21.74 \\
\hline & No response & 10 & 43.48 \\
\hline & Total & 23 & 100.00 \\
\hline \multirow{4}{*}{$\begin{array}{l}\text { Do the animals become sick } \\
\text { after re-introduction? }\end{array}$} & Yes & 2 & 8.70 \\
\hline & No & 10 & 43.48 \\
\hline & No response & 11 & 47.83 \\
\hline & Total & 23 & 100.00 \\
\hline
\end{tabular}


Table $7 \mathrm{~b}$ and $7 \mathrm{c}$ show that with exception of site for chimpanzee that is inadequate, sites are supposed to be adequate for the release of other primate species if not for encroachments that have resulted to serious reductions.

Table 7b: Assessment of site adequacy and suitability for primate re-introduction in CERCOPAN

\begin{tabular}{|c|c|c|c|}
\hline Parameter & Variable & Frequency & Percentage \\
\hline Are there adequate Sites & Yes & 21 & 91.30 \\
\hline \multirow{2}{*}{ for re-introduction? } & No & 2 & 8.70 \\
\hline & Total & 23 & 100.00 \\
\hline \multirow{4}{*}{$\begin{array}{l}\text { If the site for release is } \\
\text { increasing or decreasing? }\end{array}$} & Increasing & 6 & 26.09 \\
\hline & Decreasing & 10 & 43.48 \\
\hline & Constant & 7 & 30.43 \\
\hline & Total & 23 & 100.00 \\
\hline \multirow{7}{*}{$\begin{array}{l}\text { If decreasing, what are the } \\
\text { causes? }\end{array}$} & Inadequate security & 1 & 30.43 \\
\hline & Plantation forestry & 1 & 8.70 \\
\hline & Human population increase & 2 & 8.70 \\
\hline & Inadequate community education & 2 & 26.09 \\
\hline & Logging & 4 & 4.35 \\
\hline & Bush burning & 6 & 4.35 \\
\hline & Shifting cultivation & 7 & 17.39 \\
\hline \multirow{3}{*}{$\begin{array}{l}\text { If encroachments have } \\
\text { been experienced in the } \\
\text { park? }\end{array}$} & Yes & 23 & 100.00 \\
\hline & No & 0 & 0.00 \\
\hline & Total & 23 & 100.00 \\
\hline \multirow{3}{*}{$\begin{array}{l}\text { If yes, how was it } \\
\text { resolved? }\end{array}$} & Chiefs imposed fine on defaulters & 23 & 100.00 \\
\hline & Other methods & 0 & 0.00 \\
\hline & Total & 23 & \\
\hline
\end{tabular}

Table 7c: Assessment of site adequacy and suitability for primate re-introduction in PANDRILLUS

\begin{tabular}{|c|c|c|c|}
\hline Parameter & Variable & Frequency & Percentage \\
\hline Are there enough sites & For drill & & \\
\hline \multirow[t]{7}{*}{ for re-introduction? } & Yes & 24 & 100.00 \\
\hline & No & 0 & 0.00 \\
\hline & Total & 24 & 100.00 \\
\hline & For chimps & & \\
\hline & Yes & 0 & 0.00 \\
\hline & No & 24 & 100.00 \\
\hline & Total & 24 & 100.00 \\
\hline \multirow{3}{*}{$\begin{array}{l}\text { If the sites are increasing } \\
\text { or decreasing? }\end{array}$} & Increasing & 7 & 29.17 \\
\hline & Decreasing & 17 & 70.83 \\
\hline & Total & 24 & 100.00 \\
\hline \multirow{4}{*}{$\begin{array}{l}\text { If decreasing, what are } \\
\text { the causes? }\end{array}$} & Community infrastructure development & 7 & 29.17 \\
\hline & Bush burning & 11 & 45.83 \\
\hline & Logging & 14 & 58.33 \\
\hline & Shifting cultivation & 14 & 58.33 \\
\hline \multirow{3}{*}{$\begin{array}{l}\text { If encroachment has } \\
\text { been experienced in the } \\
\text { park? }\end{array}$} & Yes & 21 & 87.50 \\
\hline & No & 3 & 12.50 \\
\hline & Total & 24 & 100.00 \\
\hline \multirow{4}{*}{$\begin{array}{l}\text { If yes, how was it } \\
\text { resolved? }\end{array}$} & Dialogue & 2 & 8.33 \\
\hline & Arresting & 5 & 20.83 \\
\hline & The chiefs fine them & 6 & 25.00 \\
\hline & Seizing their equipments & 7 & 29.17 \\
\hline
\end{tabular}

Operational Strategies Adopted by the Organizations in Overcoming identified Challenges

Tables $8 \mathrm{a}$ and $8 \mathrm{~b}$ show that the most effective strategy adopted by the firm (CERCOPAN) as observed by the respondents is constant monitoring of the released stock $(69.57 \%)$. Others are provision of monitoring equipments
$(26.09 \%)$ and engaging in soft release $(8.70 \%)$. Table $6 \mathrm{~b}$ shows the strategies indicated by respondents from PANDRILLUS to check such potential challenges as: educating host community members $(87.50 \%)$, purchasing the monitoring equipments $(79.17 \%)$ and radio caller systems $(66.67 \%)$. 
General Problems Affecting Efficient and Effective Operations of Captive Breeding by the Organizations

Tables $9 \mathrm{a}$ and $9 \mathrm{~b}$ indicated poor health condition of staff $(65.22 \%)$, poor salary scale $(60.87 \%)$, unavailability of fund $(47.83 \%)$, and poor means of transportation $(47.83 \%)$ and deforestation $(79.17 \%)$ as major problems affecting operations in the firms.

Table 8a: Strategies adopted by CERCOPAN for overcoming identified Re-introduction challenges

\begin{tabular}{lll}
\hline Adopted Strategies & Frequency & Percentage \\
\hline Familiarizing release stock & 1 & 4.35 \\
Patrol and surveillance & 1 & 4.35 \\
Rural education & 1 & 4.35 \\
Taking the tree phonologies & 1 & 4.35 \\
Health screening & 2 & 8.70 \\
Soft release & 2 & 8.70 \\
Provision of monitoring equipments & 6 & 26.09 \\
Constant monitoring & 16 & 69.57 \\
\hline
\end{tabular}

Table 8b: Strategies adopted by PANDRILLUS for overcoming Re-introduction challenges

\begin{tabular}{lll}
\hline Adopted Strategies & Frequency & Percentage \\
\hline Imposing fine on defaulters & 6 & 25.00 \\
Arresting defaulters & 6 & 25.00 \\
Sourcing for fund from local and foreign bodies & 12 & 50.00 \\
Provision radio caller systems & 16 & 66.67 \\
Purchase of monitoring equipments & 19 & 79.17 \\
Educating the villagers & 21 & 87.50 \\
\hline
\end{tabular}

Table 9a: General problem faced by the management and staff of CERCOPAN

\begin{tabular}{lll}
\hline Problems & Frequency & Percentage \\
\hline Over population of primate & 1 & 4.35 \\
Inbreeding & 1 & 4.35 \\
Inefficient community education & 1 & 4.35 \\
Inability to raise a self sustaining population & 1 & 4.35 \\
Fighting among primates in enclosures & 1 & 4.35 \\
Insecurity of the protected area & 1 & 4.35 \\
Lack of communication gadgets & 1 & 4.35 \\
Encroachment & 1 & 4.35 \\
Aggression of older primates on younger ones & 2 & 8.70 \\
Escape of primates & 2 & 8.70 \\
Poor staff education & 2 & 8.70 \\
Attack by predators & 2 & 8.70 \\
Lack of potency of locally purchased drugs & 2 & 8.70 \\
High cost of primate health requirement & 2 & 8.70 \\
Inadequate manpower & 3 & 13.04 \\
Inadequate skilled personnel & 4 & 17.39 \\
Difficulties in feeding baby primates & 4 & 17.39 \\
Competition among inmates & 6 & 26.09 \\
Disease infection & 6 & 26.09 \\
Poor accessibility to release site & 7 & 30.43 \\
Lack of working equipments & 8 & 34.78 \\
Poor welfare packages & 9 & 39.13 \\
Poor infrastructure & 9 & 39.13 \\
Lack of fund & 11 & 47.83 \\
Poor means of transportation & 11 & 47.83 \\
Poor salary & 14 & 60.87 \\
Poor health standard of staff & 15 & 65.22 \\
\hline
\end{tabular}


Challenges of Captive Breeding and Reintroduction of Selected.................JEОМАН \& CHOKO

Table 9b: General problem faced by the management and staff of PANDRILLUS

\begin{tabular}{lll}
\hline Problems & Frequency & Percentage \\
\hline Trees falling and destroying the enclosures & 1 & 4.17 \\
Effect of seasonal changes on primates & 2 & 8.33 \\
No monitoring equipment & 7 & 29.17 \\
Escape of primates & 7 & 29.17 \\
Injury incurred by primates during fight & 9 & 37.50 \\
Lack of safety gadgets & 9 & 37.50 \\
Insufficient manpower & 10 & 41.67 \\
Lack of infrastructures & 10 & 41.67 \\
Hunting & 10 & 41.67 \\
Attack on workers by primates & 12 & 50.00 \\
Insufficient space for animals/ overpopulation & 13 & 54.17 \\
High food consumption by the animals & 14 & 58.33 \\
Competition by the animals & 17 & 70.83 \\
Deforestation & 19 & 79.17 \\
Unavailability of fund & 20 & 83.33 \\
Health challenges & 20 & 83.33 \\
\hline
\end{tabular}

Results on assessment of staff and incentive adequacy of organizations in Tables 10a and 10b show that majority of the respondents in both organizations considered the number of staff inadequate. The incentives given to workers were also considered inadequate by respondents (Tables 11a and 11b)

\section{Management Relationship with Host communities}

Results on Tables $12 \mathrm{a}$ and $12 \mathrm{~b}$ show that conservation institutions have a cordial relationship with host communities and that host communities' involvement were in the area of employment, education and species' protection.

Table 10a: Assessment of employment status of the organization by respondents (CERCOPAN)

\begin{tabular}{llll}
\hline Parameters & Variable & Frequency & Percentage \\
\hline Staff strength of the organization & Adequate & 3 & 13.04 \\
& Inadequate & 20 & 86.96 \\
& Total & 23 & 100.00 \\
If more staffs should be employed? & Yes & 23 & 100.00 \\
& No & 0 & 0.00 \\
& Total & 23 & 100.00 \\
\hline
\end{tabular}

Table 10b: Assessment of employment status of the organization by respondents (PANDRILLUS)

\begin{tabular}{|c|c|c|c|}
\hline Parameter & Variable & Frequency & Percentage \\
\hline \multirow[t]{3}{*}{ Staff strength } & Adequate & 5 & 20.83 \\
\hline & Inadequate & 19 & 79.17 \\
\hline & Total & 24 & 100.00 \\
\hline \multirow{3}{*}{$\begin{array}{l}\text { If more staff will be } \\
\text { employed? }\end{array}$} & Yes & 24 & 100.00 \\
\hline & No & 0 & 0.00 \\
\hline & Total & 24 & 100.00 \\
\hline
\end{tabular}

Table 11a: Assessment of the adequacy of incentives collected by respondents

\begin{tabular}{lll}
\hline Adequacy of incentives & Frequency & Percentage \\
\hline Adequate & 8 & 34.78 \\
Not adequate & 9 & 39.13 \\
No response & 6 & 26.09 \\
Total & 23 & 100.00 \\
\hline
\end{tabular}


Table 11b: Assessment of the adequacy of incentives collected by respondents

\begin{tabular}{lll}
\hline Adequacy of incentives & Frequency & Percentage \\
\hline Adequate & 5 & 20.83 \\
Not adequate & 19 & 79.17 \\
Total & 24 & 100.00 \\
\hline
\end{tabular}

Table 12a: Assessment of CERCOPAN's management relationship with host community

\begin{tabular}{llll}
\hline Parameter & Variable & Frequency & Percentage \\
\hline Relationship of the & Cordial & 23 & 100.00 \\
establishment & Not cordial & 0 & 0.00 \\
with the villages & Total & 23 & 100.00 \\
Are the nearby communities & Yes & 23 & 100.00 \\
involved in the management? & No & 0 & 0.00 \\
& Total & 23 & 100.00 \\
If yes, how? & Protection & 1 & 4.35 \\
& Land & 4 & 17.39 \\
& Imposing fines & 8 & 34.78 \\
& Manpower & 18 & 78.26 \\
& Education & 19 & 82.61 \\
\hline
\end{tabular}

Table 12b: Assessment of PANDRILLUS' management relationship with project host community

\begin{tabular}{lllll}
\hline Parameter & Variable & Frequency & Percentage \\
\hline Relationship & of firm with & Cordial & 18 & 75.00 \\
the villages & & Not cordial & 4 & 16.67 \\
& & No response & 2 & 8.33 \\
& & Total & 24 & 100.00 \\
Are the communities & Yes & 20 & 83.33 \\
involved & in the & No & 0 & 0.00 \\
management? & & No response & 4 & 16.67 \\
& & Total & 24 & 100.00 \\
If yes, how? & & Provision of animal feed for buying & 3 & 12.50 \\
& & Imposing fine on defaulters & 5 & 20.83 \\
& & Community education & 8 & 33.33 \\
& & Provision of information on escaped primates & 9 & 37.50 \\
& & Manpower & 15 & 62.50 \\
\hline
\end{tabular}

Table 13a: Respondents' recommendation on facilities to be provided to improve breeding and reintroduction in CERCOPAN

\begin{tabular}{llll}
\hline Parameter & Variable & Frequency & Percentage \\
\hline If more materials should & Yes & 19 & 82.61 \\
be provided for the & No & 1 & 4.35 \\
exercise? & No response & 3 & 13.04 \\
& Total & 23 & 100.00 \\
Required materials to & Educational materials & 1 & 4.35 \\
improve breeding and re- & Uniform for workers & 1 & 4.35 \\
introduction process & Communication gadgets & 2 & 8.70 \\
& Manpower & 3 & 13.04 \\
& Pens & 4 & 17.39 \\
& Animal feed & 4 & 17.39 \\
& Fund & 5 & 21.74 \\
& Security materials & 5 & 21.74 \\
& Health packages & 7 & 30.43 \\
& Construction materials & 7 & 30.43 \\
& Salary increasing & 9 & 39.13 \\
& Accessibility & 9 & 39.13 \\
& Infrastructures & 12 & 52.17 \\
& Safety gadgets & 15 & 65.22 \\
& Means of transportation & 15 & 65.22 \\
\hline
\end{tabular}


Challenges of Captive Breeding and Reintroduction of Selected................IJEOMAH \& CHOKO

Table 13b: Materials required to improve captive breeding process in PANDRILUS

\begin{tabular}{|c|c|c|c|}
\hline Parameter & Variable & Frequency & Percentage \\
\hline \multirow{3}{*}{$\begin{array}{l}\text { If more materials be } \\
\text { provided for the exercise? }\end{array}$} & Yes & 24 & 100.00 \\
\hline & No & 0 & 0.00 \\
\hline & Total & 24 & 100.00 \\
\hline \multirow{12}{*}{$\begin{array}{l}\text { Required materials to } \\
\text { improve breeding and re- } \\
\text { introduction process }\end{array}$} & Insurance of staff against hazard & 3 & 12.50 \\
\hline & Solar panels for electrification & 4 & 16.67 \\
\hline & Satellite facilities & 4 & 16.67 \\
\hline & Working kits & 5 & 20.83 \\
\hline & Roads for accessibility & 10 & 41.67 \\
\hline & Communication gadgets & 10 & 41.67 \\
\hline & Cages/enclosures & 13 & 54.17 \\
\hline & Health facilities & 14 & 58.33 \\
\hline & Transportation means & 16 & 66.67 \\
\hline & Safety gadgets & 18 & 75.00 \\
\hline & Fund & 20 & 83.33 \\
\hline & Manpower & 21 & 87.50 \\
\hline
\end{tabular}

Discussion

General Knowledge of respondents about Captive Breeding and Re-introduction of Primates

Majority of the respondents from both conservation institutions are not conversant with the processes involved in captive breeding and reintroduction of the species. This could be attributed to the low educational level of the workers as most have secondary school certificate as their highest educational qualification. More educated persons learn faster than less educated ones. This implies that both institutions are using the same strategy. It also implies that the institutions have not been giving adequate trainings on the techniques involved in the breeding and re-introduction of primates into the wild. The implication of this is that the sustainability of the programme can hardly be guaranteed since techniques for the programme are known by very few persons. It could also be attributed to the fact that the few persons who are part of the management want to remain sustainably relevant, and may not be willing to train others to acquire the necessary skills. This therefore prevents majority of the workers from understanding the processes involved in the breeding and re-introduction exercise.

Challenges Faced in the Captive Breeding and Reintroduction of Selected Primate Species in the Study Area

Respondents observed that the behavioural patterns of the released primates (Tables 5 and 6) were altered since they were bred ex-situ. They were unable to interact with the wild ones (26.09\%) and unable to cope with the forest situation $(34.78 \%)$ due to the fact that they have lost their foraging skill and the ability to escape from predators or hunters (in case poachers encroach into the release site). This implies that they have lost that sense of wildness. The returning of the released primates to the captive breeding centre cannot be unconnected with the fact that the primates are sure of free food in the breeding site where they are used to. It can also be attributed to the fact that the species while in the breeding sites were not properly "hardened up" as to be used to the wild. Also, the breeding sites were not spacious enough to serve as home range of the species in the wild and the primates were not raised to be running away from humans. This is in agreement with the work of Dellatore (2007). Among the challenges indicated by the respondents (Tables 5 and 6) include the stress and time it takes to raise a self sustaining population. Most primates spend their lives in large groups or communities as this helps them to provide protection against predation and protect their scarce food resources. Each group of primates could be up to twenty five in number and composed of few males and several females with their young ones including 'sisters' and 'aunts' acting as a team. This population ratio can be attributed to the source of the breeding stock and also makes the selection of various groups for re-introduction difficult. Time is required in order to raise this type of group that will be fit for re-introduction, as it requires close monitoring of the ones that understand themselves in the breeding stock, then separating them from the breeding stock in order to increase their understanding. In the course of preparing them to 
be released, constant screening, feeding and behavioural monitoring will be going on as the release stock keeps increasing. If the ratio of the males to the females is very close, there would be need to remove some males (to avoid fighting for territoriality, and prevent inbreeding), leaving the infants and other females. While doing all these, time and other resources are spent. For instance, since the inception of the project in CERCOPAN, according to respondents, they have released just once in 2007 and the stock was just three in number. The group was not a self sustaining one and they all returned to the breeding centre. In the case of PANDRILLUS, the respondents $(100 \%)$ reported that re-introduction has not been embarked upon since the inception of the programme in 1991. This therefore shows that it takes time to raise and select a self sustaining group to be released. This agrees with the observation of Clark et al. (2002) that the source population of primates may be in "short supply", particularly if certain age or sex groups are targeted or if the source consist of endangered stock. Besides, if these organisations are really interested in embarking on successful reintroduction exercise they would have made many attempts.

The fact that CERCOPAN did not make any other attempt to reintroduce the animals after the failed one and PANDRILLUS did not attempt any re-introduction exercise could be an indication that the intention of the organisations could be to manage the captive bred animals in perpetuity. This corroborates the findings of Hancocks as cited by Laidlaw (2001) that most conservation centres around the world create so much awareness about captive breeding and reintroduction programmes, yet only few actually participate in them in a substantive way. Even many of the high profile Species Survival Plan (SSP) breeding programmes in various parts of the world, have no mechanism for reintroduction, and virtually all of them concentrate on maintenance of captive populations in perpetuity (Laidlaw, 2001).

The other challenge as observed by the respondents is the issue of disease transmission. As observed during the research, the respondents are in contact with primates daily, and they do so without any form of protective gadget such as hand gloves and face masks. This close contact carries a considerable risk of exchange of zoonotic diseases as those carried by humans may spread to the primates and vice versa. The spread routes could be through aerosols (cough and sneezes), water contamination, bites, etc. The respondents also complained of the bacterial diseases as the ones with highest occurrence in the vicinity, hence they could be transmitted through several means. This agrees with Wolfe et al. (1998), Wallis and Lee (1999), Adams et al. (2001), Kilbourn et al. (2003) and Quammen (2007).

Respondents complained of the long duration and stressful nature of the monitoring periods and the inadequacy of monitoring materials (Table 5 and 6). This can be attributed to the fact that the primate species in CERCOPAN were released during the dry season to ease accessibility to the site because the staff has to keep on monitoring the released stock until rainy season starts - when fruits become abundant in the wild. This exercise as reported by the respondents is done manually with crude implements such as working down to the release site without any protective to supply food for them on daily basis. In the process of monitoring, some staff stay overnight with the released stocks to observe and protect them. This puts the lives of workers at risk. In the case of PANDRILLUS, re-introduction has not been carried out since the inception of the project. This can be ascribed to inadequate protective measures, lack of monitoring materials (due to high cost of purchasing them), lack of skilled personnel and the primate's health requirements (Table 6). In an interview with the vet doctor, he complained about the impotency of the locally purchased drugs unlike the ones imported from other countries which tend to be more potent. Some of the respondents $(25.00 \%)$ complained of the attitude of the community towards the project. Even with the high awareness level of the villagers about the conservation project, cases of poaching are still noticed as villagers still encroach into the gazzetted site to hunt and carry out logging operations. Despite positive overall attitudes toward primates, the attitudes of villagers towards primate re-introduction have been discouraging workers. These negative attitudes are partially associated with the perception that re-introduction will result in land use restrictions. Rural property-owning and 
resource-dependent groups tend to be more utilitarian and dominionistic in their value towards wildlife. Similarly, most workers are of the view that successful re-introduction of the primates may lead to the end of the conservation project and losing of their jobs. They therefore perceive that the captive management of these animals in perpetuity will secure their job and attract sponsorships. This attitudinal issue is in line with the work of Clark et al. (2002) and Kellert (1994).

General Problems Affecting Efficient and Effective Operations $f$ Captive Breeding by Non Governmental Organization (NGO)

Unavailability of fund, poor staff health and welfare packages, poor salary scale and lack of infrastructure had the highest cumulative percentage as problems of these conservation institutions. Due to inadequate fund, the organisations have not been able to purchase the standard equipments such as monitoring camera (that works with satellite) and patrol vehicles for the job. This hinders the organizations from employing more staff as already existing ones are not well remunerated (Table 5, 6, 9a and 9b). When sick, the organization contributes very little to hospital bills of respondents. A respondent complained of not earning up to ten thousand naira even with his years of experience and family status. Also, there is no insurance covering them should in case they are injured while carrying out their duties, whereas they are subjected to various kinds of risks. In the case of infrastructure, the road was observed to be bad as sometimes the researcher was compelled to drop and walk across water bodies before accessing the site. Lack of transport facilities makes workers trek long distances on daily basis before getting to the site to commence work. As a result of limited home range and none release of captive - bred individuals to the wild the population of the animals has exceeded the carrying capacity of the breeding centres, thus, leading to the problem of inbreeding and consequential increase in chances of disease infestation. This is in agreement with the works of Clark et al (2002), Reading and Kellert, (1993). In addition, 79.17\% of the respondents in PANDRILLUS complained of loss of habitat through deforestation due to human activities such as bush burning, logging and fuel wood collection. In spite of the villagers' consciousness of the project, they still carry out deforestation activities in the form of bush burning for shifting cultivation and bushmeat hunting, clearing for fuel wood, etc. This in turn jeopardizes the efforts of these organizations as the habitats of these primates are destroyed by these activities. White and Tutin (2001) gave a similar report that logging practices were responsible for the reduction of chimpanzee densities in Gabon.

Provision of food to animals creates competition among them especially as the food are more concentrated at locations and always provided unlike in the natural forest where they are dispersed and are available mostly on seasonal basis. Competition during feeding is a challenge, and occurs due to the fact that primates observe the principle of peck order (Social stratification). Provision of food can lead to increased proximity and aggressive competition. Primates in the form of higher ranking individuals chase away those in lower classes when being fed, which results into a serious fight that could lead to injuries, while some escape from the enclosures not considering the risk of being electrocuted. Similar result was obtained by Berman et al. (2007).

The workers in these organizations are few in number (35 and 34) with the majority having secondary level of education irrespective of required skills for type of job to be done. This also affects efficiency and obstructs free flow of activities in the project. This inadequacy of staff has also contributed to some form of insecurity of the protected site, as poachers such as loggers and hunters gain access into the reserve. The fact that most of the workers are secondary school leavers indicates that the firms lack professionals, and the few that know the job refuse to teach the others. This indicates that there is no transparency and free flow of ideas among staff of the organization. Besides, the equipments used are obsolete and few. For instance, only few workers had safety booths and all the workers had no safety coats. This reveals the high vulnerability level the workers are exposed to.

Operational Strategies Adopted by PANDRILLUS and CERCOPAN in Overcoming the Challenges Mentioned Above

Purchasing of monitoring equipments, constant monitoring, patrol and surveillance are 
the operational strategies adopted by these institutions with the hope of ensuring proper security of the project and release sites, and minimizing the activities of poachers significantly. Public education is also used to gain public support towards the project. This agrees with Clark et al. (2002) that for reintroduction programmes to succeed, public support, particularly local support secured from the onset is crucial. Other strategies include, making the primates go through soft release processes in electrified enclosures in areas close to the release site. This will in turn familiarize the release stock with the release site, harden up the primates, teaching them to forage and escape from predators or hunters and also make them become acclimatized with the forest environment.

The respondents also mentioned that the primates are constantly screened to ensure that they are disease free. The issue of inbreeding is also tackled by castrating the males and vasectomizing/implanting their female counter parts with foreign bodies to prevent the transfer of fluid fluid into the female during mating. They also engage in phenology studies. This involves knowing the vegetation characteristics, the fruiting seasons, etc. This in turn aids them in knowing the right time to release the primates and to know the kind of fruits they will feed on at the point of release.

\section{Conclusion}

Both CERCOPAN and PANDRILLUS are facing similar challenges in their captive breeding and re-introduction programme. Major among these challenges include deforestation/loss of habitat, hunting and insecurity of the protected/gazetted area; which are usual challenges faced in protected areas. Then, on a general platform, they encounter challenges such as lack of finance, lack of skilled personnel, poor welfare and health standard of the staff and insufficient materials for the captive breeding and re-introduction processes. If these challenges are not overcome, or if the materials required for this exercise to be efficient and effective are not made available, the aim of establishing these organizations will be defeated and the wild populations of these primates will decrease continuously till it gets to the point of extinction.
This is because the aim of setting these centres is to reinforce the populations in the wild.

The operational principle of the two organizations is similar. Information on strategy for re introduction is known by very few workers. And this information is hoarded even from up coming wildlife experts who could benefit from such knowledge. In reality the two centres are managed only as breeding centres; which can serve as a tourist attraction. The fact that CERCOPAN and PANDRILLUS have operated for 15years and 20years respectively without success record in re introduction of species into the wild shows that they are performing below expectation. Even when re introduction attempt was made, only three individuals were involved and the animals later returned to the breeding centre. Successful re - introduction of only three individuals of primate in twenty years could not had made much significance at global level (considering the gestation period and litter size of species involved) if the only re introduction attempt worked. The organizations seem to be afraid of losing their sponsorship if re introduction of many individuals into the wild is achieved, hence they embark on tactical delays.

\section{Recommendations}

For the successful breeding and reintroduction of these primates in the breeding centres, more funds should be allocated to the programme by the government and the NonGovernmental Organizations involved. The government should also train more individuals so as to know the nitty-gritty of the exercise. The sponsors of these institutions should state clearly and be very serious with the time given to these organizations to achieve their set targets.

On the part of the organization, they should employ more staff that are skilled and also increase/improve their welfare packages so as to make them comfortable. More materials should also be provided for monitoring these primates during breeding and after final release.

\section{References}

Adams, H. R., Sleeman, J. M., Rwego, I. and New, J. C. (2001). Self-Reported Medical History Survey of Humans as a Measure of Health Risk to the Chimpanzees (Pan troglodytes schweinfurthii) of Kibale 
Challenges of Captive Breeding and Reintroduction of Selected..................JEOMAH \& CHOKO

National Park, Uganda. Oryx 35(4): 308-312.

Berman, C. M., Li, J., Ogawa, H., Ionica, C. and Yin, H. (2007). Primate Tourism, Range Restriction and Infant Risk among Macaca thibetana at Mt Huangshan, China. International Journal of Primatology In press.

Clark, J. D., Huber, D. and Servheen, C. (2002). Bear Re-introductions: Lesson and Challenges. Thesis, University of Tennessee, Knoxville, Tennessee, USA. 345pp. Conservation and Science, 2012, A legacy of Conservation. Arizona Zoological Society, 19:1

Defenders of Wildlife (2012). Places for the Wolves - The Southeast. Defenders of Wildlife, Washington D.C. p.1-2 defendersofwildlife.org, $\quad$ Retrieved February, 2014

Dellatore, D.F. (2007). Behavioural Health of Reintroduced Orangutans (Pongo abelii) in Bukit Lawang, Sumatra Indonesia. A Dissertation Submitted in Part Fulfillment of the Requirements for the Degree of Master of Science in Primate Conservation Oxford Brookes University. $72 \mathrm{pp}$.

Fascione, N. (2006). Places for Wolves. Defenders of Wildlife, Washington D.C. 40pp.http://www.defenders.org/publication s/places_for_wolves_2006.pdf Retrieved March, 2014

Forest Resource Solution Ltd (2006). EcosystemBased Natural Resource Management in the Forest of Cross river state. Prepared for: The Canadian International

Development Agency (CIDA) And One Sky-Canadian Institute of Sustainable Living. 54pp.

Ijeomah, H.M., Alarape, A.A. and Adetoro, O.A. (2006). Breeding Potency and History of Selected Animal Species in Jos Wildlife Park. Bowen Journal of Agriculture, Iwo, $\begin{array}{lll}\text { Osun } & \text { State. } & \text { 3(2): }\end{array}$ http://www.ajol.info

Ijeomah, H.M., Ofodile, E.A.U. and Esaen, N. (2012). Management of Endangered Wildlife species in captivity:Case studies of the Lion (Panthera leo) and the African
Elephant (Loxodonta africana) In: Reorganizing Nigeria's Forestry in the Rapidly Changing Climatic Conditions: Challenges and Solutions. Proceedings of the second annual conference of the Association of women in Forestry and Environment, held in the Forestry Institute of Nigeria, Jericho, Ibadan on 6th November, 2012

IUCN (2013). IUCN Red List of Threatened Species. Version 2013.2. $<$ www.iucnredlist.org $>$.

Jim, H. (2010). The story of Simon Ndege. Africa Answerman. Published Online.Retrieved May, 2011.

Kellert, S.R. (1985). Social and perceptual factors in endangered species management. Journal of Wildlife Management 49: 528536.

Kilbourn, A. M., Karesh, W. B., Wolfe, N. D., Bosi, E. J., Cook, R. A. and Andau, M. (2003). Health Evaluation of FreeRanging and Semi-Captive Orangutans (Pongo pygmaeus pygmaeus) in Sabah, Malaysia. Journal of Wildlife Diseases 39(1): 73-83.

Kehinde, O. A. and Ijeomah, H.M (2012). Challenges of Ex -situ Wildlife Management in Nigeria: Zoological gardens in perspective, In:Ijeomah, H.M. and Aiyeloja, A.A.(eds.).Challenges to Sustainable Production in Agriculture and the Environment: Nigeria in Perspective. Top Base Nigeria Limited, Lagos, in Conjunction with Green Canopy Consultants, Port Harcourt, Rivers State.

Kumar, K. (2006). Slow Death Agony for Lions After Failed Breeding Program. http://www.dailymail.co.uk/news/article406115/Slow-death-agony-lions- failedbreeding-program.html\#ixzz1NBHiD. Retrieved May, 2011

Laidlaw, R. (2001). Re-introduction of captivebred animals to the wild: Is the modern ark afloat? In: APA (6th ed.)Who cares for planet Earth?: The CON in conservation. Brighton, Portland, OR: Alpha Press.

Macdonald, D.W., Moorhouse, T.P., Enck, J.W. and Tattersall, F.H. (2002). Mammals Handbook of Ecological Restoration: Principles of Restoration eds. M.R. Perrow 
and A.J. Davy), Pp. 389-408. Cambridge University Press, Cambridge

National Wildlife Federation (2014). Wildlife Overexploitation, http://www.nwf.org/wildlife/threats-towildlife/overexploitation.aspx

Quammen, D. (2007). Deadly Contact: How Animals and Humans Exchange Disease. October ed. National Geographic.

Tamarin Tales (2010). Metapopulation Management of Golden Lion Tamarins, volume 10:1-20.

http://nationalzoo.si.edu/SCBI/EndangeredSpecie s/GLTProgram/Tamarins/TamarinTales10. pdf Retrieved February, 2014.

Van Wieren, S.E. (2006) Populations: reintroductions. Restoration Ecology:The New Frontier (eds J. van Andel \& J. Aronson), pp. 82 - 92. Blackwell Publishing, Malden, USA
Wallis, J. and Lee, D. R. (1999). Primate Conservation: The Prevention of Disease Transmission. International Journal of Primatology, 20(6): 803-826.

White, L.J.T. and Tutin, C.E.G. (2001). Why chimpanzees and gorillas respond differently to logging: A cautionary tale from Gabon. In: W. Weber, L.J.T. White, A. Vedder and L. Naughton-Treves (eds.), African Rain Forest Ecology and Conservation: An Interdisciplinary Perspective, pp.449-462. Yale University Press, New Haven

Wolfe, N. D., Escalante, A. A., Karesh, W. B., Kilbourn, A., Spielman, A. and Lal, A. A. (1998). Wild Primate Populations in Emerging Infectious Disease Research: The Missing Link? Emerging Infectious Diseases, 4(2): 149-158. 